\title{
The Relationship between Parental Coat Colour and Prize-winning Palominos
}

\author{
Holly E. BILLINGTON ${ }^{1}$ and Neil R. McEWAN ${ }^{1 *}$ \\ ${ }^{1}$ Institute of Biological, Environmental and Rural Sciences, Aberystwyth University, Aberystwyth, SY23 3AL, \\ Wales, UK
}

Although various combinations of parental coat colours can produce a Palomino foal, examination of records of the British Palomino Society suggest that many animals registered with the society resulted from matings which maximise the likelihood or even guarantee a Palomino foal. When show records were examined, it was clear that the colouration preferred by judges corresponds to that of the only pair-wise parental combination guaranteeing a Palomino foal.

Key words: Palomino, prize-winning, selective breeding
J. Equine Sci.

Vol. 20, No. 4

pp. 73-77, 2009
Some horses are bred for specific functions, such as ability to race, compete in jumping events or tasks such as pulling a plough. Others are selected for their physical appearance, such as traits like height or colour. Palominos fall into the latter category, being selected based on their colouration. The Palominos are not a breed, but rather are horses, from various breeds, with a similar range of colouration. A Palomino can be any breed but must have a golden coat and a white mane and tail, though the shade of gold can vary. Hence a range of coat colours fit the requirements needed to be a Palomino, ranging from a light appearance to a more sooty dark appearance.

Many countries have a society devoted to promotion of animals of this colour, e.g. the British Palomino Society. In order that an animal may become registered with one of these societies, it must be inspected to ensure that its colouration falls within the Society's guidelines. Many of these horses are exhibited in Palomino classes at local and national shows. As with other horse types which are characterised by the animal's colour (e.g. Piebalds), Palominos are judged predominantly on colour, with $80 \%$ of the marks given to colour and $20 \%$ for factors such as conformation.

The genetics of horse coat colour is complex, and is

This article was accepted October 16, 2009

*Corresponding author. e-mail: nrm@aber.ac.uk controlled by a combination of several genes, each of which may have multiple alleles [1]. However, the most important of these loci for Palominos is on chromosome 21 [3]. Here a single transition mutation [4] results in the cremello $\left(C^{C r}\right)$ allele which shows incomplete dominance over the wild-type $\left(C^{+}\right)$, giving a diluting effect on coat colour [5]. Palomino horses are heterozygous $\left(C^{+} C^{C r}\right)$ at this locus. Taking other loci taken into account, a basal chestnut coat colour can be chestnut when homozygous wild type $\left(C^{+} C^{4}\right)$, cremello when homozygous cremello $\left(C^{C r} C^{C r}\right)$ or palomino when heterozygous $\left(C^{+} C^{C r}\right)$. Horse breeders wishing to ensure a Palomino offspring will cross a Chestnut with a Cremello, thereby producing a horse which should meet requirements for Palomino Society membership.

Whilst a Chestnut $\times$ Cremello is the only way to guarantee a Palomino, it is not the only way possible to breed a Palomino. For example, crossing two Palominos will result in $50 \%$ of the offspring being Palomino [2]. Similarly, the guaranteed Palomino cross may not necessarily produce the most successful animals in terms of show success. It may be possible that when a Palomino is born to one of the parental crosses which could produce, but does not guarantee, this colouration actually results in an animal which meets the desired show characteristics better than the Chestnut and Cremello cross. Taking this into account, we are unaware of any previous study which investigated the different levels of success achieved by 
Table 1. Colour combinations which have produced a registered Palomino in the society within the last 25 years

\begin{tabular}{|c|c|c|c|c|c|c|c|c|c|c|}
\hline & Bay & Black & Chestnut & Cremello & Dun & Grey & Palomino & Piebald & Roan & Skewbald \\
\hline Bay & 1 & & & & & & & & & \\
\hline Black & 1 & 0 & & & & & & & & \\
\hline Chestnut & 7 & 6 & 22 & & & & & & & \\
\hline Cremello & 26 & 5 & 356 & 2 & & & & & & \\
\hline Dun & 24 & 2 & 61 & 2 & 3 & & & & & \\
\hline Grey & 8 & 2 & 31 & 12 & 6 & 6 & & & & \\
\hline Palomino & 19 & 7 & 117 & 14 & 6 & 12 & 51 & & & \\
\hline Piebald & 1 & 0 & 0 & 0 & 0 & 0 & 0 & 0 & & \\
\hline Roan & 1 & 1 & 1 & 3 & 2 & 2 & 7 & 0 & 1 & \\
\hline Skewbald & 2 & 0 & 4 & 2 & 1 & 1 & 1 & 0 & 0 & 1 \\
\hline
\end{tabular}

Data in shaded boxes were removed from analysis since this parental combination cannot produce a Palomino.

Palominos originating from different parental coat colours and those most successfully exhibited as show animals.

This work aims to investigate if there is a relationship between prize-winning Palomino horses and the coat colour of their parents.

\section{Materials and Methods}

Registration details of all 2,431 horses registered with The British Palomino Society were collected for the period 1983-2007 inclusive. Of these animals, the coat colour of both parents was provided for 1,047 animals. A further 207 animals were removed from the analysis as the true coat colour described for one or more parents was impossible to identify from the colour supplied. A further 39 animals (shaded in grey in Table 1) were removed from the analysis since parents with these combinations of details cannot produce Palomino offspring (e.g. Chestnut $\times$ Chestnut). However animals where there was ambiguity regarding the exact colouration (e.g. grey which could be represented by one or more recognised coat colour), were kept in the analysis, provided they could be explained by one of the possible sources of Palomino offspring listed in [5]. Therefore 801 animals were used in the study. Details of the animal's name and the coat colour of both parents were collated.

Throughout the year the society hold shows varying from small county shows to a large annual national championship. Many classes at local shows may only have one or two horses exhibited. To ensure that the results were comparing like with like, the data analysed focused entirely on the British Palomino National
Championship Show, where each class generally has more animals exhibited than would be the case in local shows. At this show there are two major categories (ridden and in-hand) with in-hand classes placing more emphasis on colouration of horses $(80 \%$ of available marks). Since the National Championship has the greatest number of exhibitors and the emphasis on colour is greatest for in-hand classes, the investigation into show success was restricted to animals placed in the in-hand classes at the National Championships in the following nine categories: under $148 \mathrm{~cm}$ stallion, mare, yearling, 2 \& 3 year old; over $148 \mathrm{~cm}$ stallion, mare, yearling, 2 \& 3 year old and geldings 4 years and over. All animals exhibited at the show fell into only one of these classes. Registration details for all animals placed (i.e. top four prizes) in any of these classes were consulted from the database. In the first instance, this analysis took no account of which prize an animal won and also took no account of how many times an animal won a prize (e.g. in consecutive years). It also meant that any animal which had been placed but did not fall into the group of 801 (e.g. one of the 1,630 animals where both parents could not be identified) were not included in the analysis of prize winners. The relative distribution of parental coat colours between all 801 animals registered and the 90 which had been placed at shows was calculated.

$\chi^{2}$ analysis was performed to compare relative values of parental coat colour between those animals registered with the Society, and those placed at the National Show. Those combinations for which the expected value was less than 5 were treated as a single group in analysis, meaning that five groups were used: Chestnut $\times$ Cremello; Chestnut $\times$ Dun; Chestnut $\times$ Palomino; Palomino $\times$ Palomino; and all others. 
Table 2. Colour combinations which have produced a prize-winning Palomino at the Society's show within the last 25 years

\begin{tabular}{|c|c|c|c|c|c|c|c|c|c|c|}
\hline & Bay & Black & Chestnut & Cremello & Dun & Grey & Palomino & Piebald & Roan & Skewbald \\
\hline Bay & 0 & & & & & & & & & \\
\hline Black & 0 & 0 & & & & & & & & \\
\hline Chestnut & 0 & 0 & 1 & & & & & & & \\
\hline Cremello & 6 & 0 & 60 & 0 & & & & & & \\
\hline Dun & 0 & 0 & 1 & 0 & 0 & & & & & \\
\hline Grey & 0 & 0 & 2 & 1 & 0 & 0 & & & & \\
\hline Palomino & 1 & 1 & 7 & 1 & 0 & 0 & 9 & & & \\
\hline Piebald & 0 & 0 & 0 & 0 & 0 & 0 & 0 & 0 & & \\
\hline Roan & 0 & 0 & 0 & 0 & 0 & 0 & 0 & 0 & 0 & \\
\hline Skewbald & 0 & 0 & 1 & 0 & 0 & 0 & 0 & 0 & 0 & 0 \\
\hline
\end{tabular}

The value in the shaded box was removed from analysis since this parental combination cannot produce a Palomino. There were significantly more prize-winning Palominos from the Chestnut $\times$ Cremello crosses relative to the relative abundance in the figure expected from registration details $\left(\mathrm{P}=2.8 \times 10^{-5}\right.$ for $\chi^{2}$ analysis; $\mathrm{P}=4.5 \times 10^{-11}$ for Fisher's exact probability test).

Due to certain factors having expected values which were low, this analysis was repeated using Fisher's exact probability test.

\section{Results}

Table 1 shows that the largest number of registered Palominos in this work, where the coat colour of both parents could be identified, came from a Chestnut $x$ Cremello mating, which is the only parental cross which guarantees a Palomino offspring. Since 356 of the animals (i.e. 44\%) in this study were this type of cross, these data are supportive of the hypothesis that a large proportion of Palominos registered with the society were intentionally bred for their colouring.

Table 2 shows that the largest number of the Palominos placed at least once at the national championships also came from a Chestnut $\times$ Cremello mating. Hence of the 90 (following removal of 1 animal shaded in grey) animals placed during this time, 60 (i.e. $67 \%$ ) resulted from the only mating type guaranteed to give Palomino offspring.

Both tables show that a large number of animals either registered with the Society or placed at the National Championship are the result of a Chestnut $x$ Cremello mating. Moreover, the percentage of horses resulting from a Chestnut $\times$ Cremello mating is higher for animals placed at the show than it is for the list of animals registered. Given this observation a $\chi^{2}$ calculation was performed to determine if the number of Chestnut $\times$ Cremello animals which were placed at the national championship was significantly higher than the figure based on that expected from registration details. Since the expected number of some parental combinations was low (i.e. less than 5) the only pair-wise combinations which could be used to derive an expected value were: Chestnut $\times$ Cremello; Chestnut $\times$ Dun; Chestnut $\times$ Palomino; and Palomino $\times$ Palomino. All other combinations where an animal had been registered with the society (e.g. Bay $\times$ Palomino) were treated as a single expected value. This resulted in the two datasets being different $\left(\mathrm{P}=2.8 \times 10^{-5}\right)$ with proportionally more of the Chestnut $\times$ Cremello matings being successfully exhibited relative to those registered. When the analysis was repeated using Fisher's exact probability test to compensate for the fact that certain expected values were low, this also suggested that the differences between the populations was significantly different $\left(\mathrm{P}=4.5 \times 10^{-11}\right)$.

It is also interesting to note from Table 2 that every single animal which was placed at the show over the last 25 years whose parents' coat colours could be identified had at least one parent which was a Palomino, a Chestnut or a Cremello, and 77 of the 90 had both parents falling into one of these colourings.

When the analysis was restricted to only those horses which won first prize in a particular class at the National Championships, only 35 horses could be identified where the colouration of both parents had been recorded (Table 3 ). Of these animals 22 (63\%) arose from a Chestnut $\times$ Cremello mating. The remaining animals were Chestnut $\times$ Bay (4); Palomino $\times$ Palomino (3); Chestnut $\times$ Palomino (2) and 1 each of Black $\times$ Palomino, Chestnut $\times$ Dun, Chestnut $\times$ Skewbald and Cremello $\times$ Grey. Thus the values for considering 
Table 3. Colour combinations which have produced a Palomino which won first prize in its class at the Society's show within the last 25 years

\begin{tabular}{|c|c|c|c|c|c|c|c|c|c|c|}
\hline & Bay & Black & Chestnut & Cremello & Dun & Grey & Palomino & Piebald & Roan & Skewbald \\
\hline Bay & 0 & & & & & & & & & \\
\hline Black & 0 & 0 & & & & & & & & \\
\hline Chestnut & 0 & 0 & 0 & & & & & & & \\
\hline Cremello & 4 & 0 & 22 & 0 & & & & & & \\
\hline Dun & 0 & 0 & 1 & 0 & 0 & & & & & \\
\hline Grey & 0 & 0 & 0 & 1 & 0 & 0 & & & & \\
\hline Palomino & 0 & 1 & 2 & 0 & 0 & 0 & 3 & & & \\
\hline Piebald & 0 & 0 & 0 & 0 & 0 & 0 & 0 & 0 & & \\
\hline Roan & 0 & 0 & 0 & 0 & 0 & 0 & 0 & 0 & 0 & \\
\hline Skewbald & 0 & 0 & 1 & 0 & 0 & 0 & 0 & 0 & 0 & 0 \\
\hline
\end{tabular}

Chestnut $\times$ Cremello animals winning first prize versus those for any of the four places, are relatively similar $(67 \%$ versus $63 \%)$.

The second category investigated was one which extended beyond the National Championship, and looked at a points scheme, whereby horses are awarded a certain number of points every time that they are placed at any show at which points are available. Here analysis was restricted to horses which finished in the top eight for their cumulative score for any particular year. This allowed only 22 horses to be studied where the colouration of both parents could be identified. Of these horses, 13 (59\%) were the product of a Chestnut $\times$ Cremello mating with the remaining horses being Palomino $\times$ Palomino (5); Chestnut $\times$ Palomino (2); and Cremello $\times$ Bay (2). However, interestingly of the 7 horses which won the annual points scheme (with one of the horses winning it in two consecutive years), only one horse (a Chestnut $\times$ Palomino) was not the result of a Chestnut $\times$ Cremello mating.

\section{Discussion}

This work is constrained by some potential limitations in terms of conclusions which may be drawn. For example, judging of animals always has a degree of human subjectivity associated with it. Moreover, many animals which are registered with the society may never be exhibited. Hence it is possible that some of the animals which could have been prizewinning stock were not given the opportunity to fulfil their potential. In addition, due to restricted information being provided to the society by owners at the time of registration, only around a third of horses registered with the society met the criteria regarding parental information needed for inclusion in these analyses. Despite these possible limitations, one observation is very interesting, that the showing success achieved by the only possible parental combination which guarantees a Palomino foal is disproportionally larger than that seen for registration of foals with the society. This is true for all definitions of success investigated: horses winning any prize at the National Championship; horses winning first prize at the National Championship; horses which finished in the top 8 of the annual points scheme; and horses which won the annual point scheme.

The reasons for this are uncertain, as there are a range of shades which are acceptable for society membership and a range of parental combinations which can achieve a Palomino offspring. The precise shade of the Palomino is not something which is recorded. This is true for both the initial inspection at the time of society registration, and also for horses being exhibited at shows. Part of the reason for this is that the colour of the horse can vary (e.g. bleaching of hair colour following periods in the sun). Exactly what is causing the observations we report here is unclear. However, it appears that the possible shade, or shades, of coat colour resulting from Chestnut $\times$ Cremello matings are also those which are most likely to appeal to judges at shows. This in turn poses an additional question; has the Society's ideal colour definition been influenced in favour of matings which are most likely (or even guaranteed) to produce a Palomino foal? The evidence presented here suggests that this is very likely. 


\section{Acknowledgements}

The assistance of the British Palomino Society is gratefully acknowledged, in particular Mrs P. Howell and Mrs J. Maskill. We also thank Mrs J. McEwen for allowing us access to back issues of the society's journal.

\section{References}

1. Adalsteinsson, S. 1974. Inheritance of the palomino color in Icelandic horses. J. Hered. 65: 15-20.
2. Castle, W.E. 1946. Genetics of the Palomino Horse. J. Hered. 37: 35-38.

3. Locke, M.M., Ruth, L.S., Millon, L.V., Penedo, M.C.T., Murray, J.D., and Bowling, A.T. 2001. The cream dilution gene, responsible for the palomino and buckskin coat colours, maps to horse chromosome 21. Anim. Genet. 32: 340-343.

4. Mariat, D., Taourit, S., and Guerin, G. 2003. A mutation in the MATP gene causes the cream coat colour in the horse. Genet. Select. Evol. 35: 119-133.

5. Sponenberg, D.P. 2009. Equine Color Genetics. 3rd ed., pp. 225-254, Wiley-Blackwell, Iowa. 